\title{
Overcoming educational barrier as social exclusion descension in the way of life of rural youth
}

\author{
Maxim Kuzhelev ${ }^{1 *}$ \\ ${ }^{1}$ Don State Technical University, Gagarina sq., 1, Rostov-on-Don, 344003, Russia
}

\begin{abstract}
The article deals with highlighting various viewpoints upon the nature and definition of the phenomenon of «social exclusion». Though the author stresses the main accent on the exclusion in the way of life of Russian rural youth, numerous aspects of exclusion impact on different social groups of people in the world have been taken into account. The author makes an attempt to formulate his own terminology on "social exclusion» based on complex application of scientific approaches. The key issue of «social exclusion» arise lies thorough investigation of various social and economic barriers which occur on the way of Russian rural youth to society integration. The outcome of this process results in reduction of life claims within the young people community and deprived socialization. This may lead in the future to insufficient social role acquiring and descending mobility.
\end{abstract}

\section{Introduction}

Liberal market reforms have radically changed the social, group and demographic structure of Russian society. For three decades the country has been experiencing an excessively high level of social inequality, demographic insufficiency, territorial-age disproportion of human capital. These and many other negative consequences of social reforms are constantly at the center of sociological research.

For most of them, the way of life of the younger generation born in the post-Soviet period has become the sought-after support in understanding and interpreting the transformation processes taking place in the country. The problem of socio-cultural parameters and prospects of the way of life of rural youth in Russia that has developed over the post-Soviet period is one of them. Today rural youth are the most disadvantaged social group in their rights and freedoms. According to the statistics of income and property differentiation of the Russian population, it is this differentiation that makes up a large share of the poor part of the Russian population. In addition, rural youth are demographically the smallest and rapidly decreasing age group. Of the 37 million rural residents of the country, about a third are young people aged 15 to 25 . Not only because of insufficient material and property support, but also poor-quality general and vocational

*Corresponding author: kuzhelev@,hotmail.com 
education, unemployment, low level of development of social and cultural infrastructure in rural settlements, their young residents cannot maintain a generally accepted way of life.

Young generation growing up in the course of transitive society development always comes in action with a great number of sociocultural obstacles which are a result of unbalanced social-economic state policy. Poverty, low-income family background are not the only factors that influence the way of life chosen by young people. It is being formed under pressure of multidimensional social processes. Social exclusion is one of the main ones which attracts strong attention of scientists from many countries. It is referred to when it becomes necessary to explain the social problems of different demographic groups (young people, the elderly, persons with disabilities), when a comprehensive assessment of the reasons for the migration mood of the population, a decrease in the level of life aspirations is required.

It is especially important to study social exclusion in the framework of research on the lifestyle of young people, especially their rural representatives. The village, as a separate unique territorial unit, is an integral part of the Russian society with its own unique social structure and special way of life, mainly focused on agricultural production. Under these conditions, rural youth grows and develops, experiencing the consequences of social exclusion to one degree or another.

This term appeared in the social sciences relatively recently and still requires close attention from the scientific community and authorities, since its consequences radically affect the mood of the population and thereby determine the depressive nature of the development of society as a whole.

Shimi Friedman and Miriam Billig [1] wrote about the difficulties of integrating young people from isolated rural communities. Niki Black, Mark Shucksmith, Karen Scott point out the impact of the 2008 crisis on rural youth in England, speaking of the secondary impact austerity, producing further social riskiness and deepening poverty of the most vulnerable groups [2]. Social exclusion affects researchers from many countries and in different aspects: different criteria for understanding this phenomenon [3], its impact on the elderly in New Zealand [4], the impact of low mobility on the emergence of exclusion [5] and many other social problems [6-14].

\section{Materials and methods}

The statement of L.I. Belyaeva, L.T. Volchkova, V.N. Minina of intensive processes of polarization of the social structure into "rich" and "poor" $[15,16]$, mass phenomena of deprivation and social exclusion in Russia at the beginning of the XXI century [ 17, 18, 19] directly affects the villagers as an organic part of the social structure. Specialists in the field of rural sociology - P.P. Veliky, M.Yu. Morekhina, S.A. Nikolsky, V.V. Patsiorkovsky [20, $21,22]$ note a large-scale and disproportionate stratification of rural residents in accordance with the rural lifestyle, a certain way of agricultural production, as well as a system of rural settlement in the country. Sociologists regularly refer to such components of the concept of a way of life as its level, quality, way of life, and the state of the socio-cultural infrastructure of the village is surely in their field of vision. From V.I. Staroverov's point of view, the Russian village socio-cultural space "has entered the stage of systemic degradation" [23], which forms a radically different social image of the village than in the post-Soviet period and is currently special. As the author notes, today rural youth are the smallest socio-demographic group, but at the same time they are the necessary human potential not just for the survival of the Russian countryside, but for the reproduction of the whole society.

The problem of the reproduction of rural youth, namely the situation of contradictions and disproportions in their socialization, employment, life plans and preferences, is 
investigated by I.O. Karpukhin, K.V. Rubchevsky, G.A. Cherednichenko [24, 25, 26]. The adaptive approach adherers focused on the research and identification of typical / atypical ways of joining rural youth into society. It should be mentioned that the destinctive feature of their socialization is the transition from the primary to the secondary stage of socialization.

Native supporters of the riskological approach - Yu.A. Zubok, V.V. Morozov, A.P. Skrobov, V.I. Chuprov, O.N. Yanitskiy [27, 28, 29, 30], believe that the limited life resources Russian, including rural youth and the risk of their social exclusion is caused by the state of the value-normative uncertainty of Russian society. Like the supporters of the adaptation approach, the authors of the riskological approach point to the deprivation "effects" of the current stratification of Russian society. Meanwhile, they believe that the influence of education and the intellectual content of labor has weakened in the social stratification of youth.

Since the 80 s of the XX century, Western scientists and politicians have begun using the term "social exclusion". This term was based on the P. Townsend's concept of relative poverty. The EU Council of Ministers in December 1984 "presented the following understanding of poverty: these are people, a family or a group whose resources (material, cultural and social) are so limited that they exclude them from the minimum acceptable way of life that the rest of the inhabitants of those European countries where they reside. Thus, poverty is a negative deviation (deviation) from the societal norm of life due to limited resources" [31].

In the $90 \mathrm{~s}$, instead of social exclusion, the term social exclusiveness began to be used [32]. Politicians and scientists began to use new terminology - "people with various disabilities" - concerning socially excluded from society groups, such as unemployed, lowincome, people with low educational level, with disabilities, or poor health, subjected to discrimination. These groups do not have access to many services. Deviation from the norm made an obstacle to be included in society. These drawbacks are real "barriers" to inclusion" that underlie exclusion / inclusion, namely, separation / exclusion and connection / inclusion of individuals or groups in various social communities, groups and their interactions.

From the point of view of various methodological approaches (riskological, adaptive, resource, stratification, structural-differential), the manifestation of social exclusion in the lifestyle of its representatives is influenced by belonging to certain socio-economic groups (village dwellers, big families, families with at least two children, unemployed). The external environment, which limits the access of representatives of this social group to resources, the special nature of the process of modernization of Russian society, in which there is no sufficient reflection for the transition to the next stage of modernization, the stratification model of education, which has turned the Russian education system into a mechanism for the reproduction of the upper strata of society, a marker of social prestige [21, 28, 29, 33].

Paul Littlewood and the team of authors [34] also do not provide a precise definition of the phenomenon of "social exclusion". It is treated as a given. The authors discuss the appearance of the term itself in the late $60 \mathrm{~s}$ and 70 s of the last century and analyze various approaches and scientific discourses, whose object was the concept of "social exclusion" in the late 90 s of the 20th century. Some scholars (Brown, Crompton) have focused on various aspects of economic exclusion, or rather, on the restrictive effects of economic restructuring. Other scholars have limited the use of the concept of "social exclusion" to the analysis of poverty (J. Rodgers, Gore, Walker). While some (M. Roche, R. van Berkel) studied it exclusively within the political dimension. But the most famous scholars, such as Bill Jordan [35], have conducted research with the aim of developing the most holistic 
theoretical approaches based on the concept of social exclusion. Although his main focus was poverty.

The team of authors considers the following trends as the driving forces of social exclusion:

- the presence of a high level of general unemployment and underemployment, especially among young people, as well as an increase in unsafe and risky employment

- a relative or absolute decrease in physical labor employment and a corresponding increase in employment in non-productive sectors ("white collars")

The authors give examples of definitions of "social exclusion", for example, M. Roche, R. van Berkel [36], who distinguishes the concept of SE in a narrow and broad sense. In a broad sense, $\mathrm{SE}$ are those structures (lifestyles) in which certain strata of society as a whole can be considered, to a greater or lesser extent, excluded from the diversity of economic, social, political and cultural resources and activities: in the narrow sense, SE depends more on economically entrenched inequalities in employment and income levels.

According to H. Silver [37], exclusion is a vague term, burdened with numerous economic, social, political and cultural meanings and concepts, and that the very concept of "exclusion" is so ambiguous, multi-conceptual and flexible that it can be defined in different ways.

In this regard, accumulating a common understanding of the phenomenon of "social exclusion" and relying on its complex, multi-paradigmatic interpretation, we can formulate the following definition: social exclusion of rural youth is a multidimensional process of excluding representatives of this socio-demographic group from the life of society due to limited access resources and the presence of socio-economic barriers in the activities of this socio-demographic group, which complicates its social integration and thus prevents the correct socio-economic identity of its representatives.

\section{Discussion}

In comparison with the urban young people lifestyle, rural youngsters "are faced with a lack of a developed social infrastructure, primarily in the field of education and medical services, low incomes, poor living conditions, etc". [38]

Education is increasingly becoming a factor in the success of young people, in connection with which it becomes necessary to understand the difference between mass, elite and elite education and its accessibility for young people from families with different backgrounds (educational, social, material).

Mass education is characterized by "a large flow of students, with the standardization of training programs and with the involvement of new strata of social society in the university." It is considered as a kind of investment "with a subsequent return on the labor market" [39].

Mass education is designed to play the role of a social elevator for a more successful integration of the individual into society, as well as "to increase their social status," weight "in the eyes of others, to acquire new significant privileges corresponding to the achieved social status" [40].

In the social sciences, there are several concepts of understanding "elite" and "elitism". Plato (opposed the participation of the demos in political governance), Machiavelli (dividing the elite into "lions" and "foxes", in the struggle between the nobility and the people still choosing the people because of its more honest goal), G.P. Fedotov, I.A. Ilyin, who connected the elite with the most gifted representatives of society, capable of state activities, ready to sacrifice for the sake of others [41, 42].

The adjective "elite" refers to the best of its kind, the highest quality, while "elitist", being the first paronymic pair, means "intended for the privileged part of society, belonging 
to the elite." Thus, given the presence of such attributes as "elite" and "elitist" in social reality, we can talk about a radical differentiation of the opportunities for obtaining quality education for young people with different material status. "Elite education", by its nature, prepares the elite in certain spheres of activity by providing special conditions for capable and gifted children. It is characterized by a high level of teaching, focus on expanding the general outlook, universality of knowledge.

"Elitist education" is a closed system, into which one can get into not so much on the conditions of mental giftedness, as on the uniqueness of origin, "blood". Thus, the product of such an education can be predetermined for work in specific areas of politics and economics (public service, municipal activities, large financial institutions).

The result of this tacit division into "friends" and "aliens" is the unfair spread of specialized educational institutions (both higher and secondary) between the periphery and the center of the country.

A significant part of the universities that topped the first lines of the ratings are in Moscow (Moscow State University, Bauman Moscow State Technical University, NRU HSE), St. Petersburg and several regional federal institutions (UrFU, SFedU, TSU), access to which is closed for absolute the majority of rural youth, who are deprived of a significant number of social advantages (institutions of additional education, a wide network of tutors to prepare for the exam, the opportunity for rural schoolchildren to participate in Olympiads, competitions, many of which are held online) due to the remoteness of many settlements from district and regional / regional centers and dispersion of the population.

Considering the educational opportunities of young people in general, it is necessary to separate urban and rural youth due to the gap in the volume and level of their starting positions. The multifaceted transition to market mechanisms of economic management could not but affect all spheres of the social, economic, cultural, demographic life of the country, significantly affecting the most vulnerable segments of the population, among which there are rural youth. According to statistics, it is this group of the population that is the most vulnerable in terms of rights and freedoms and makes up the majority of the poor population of the country. The reasons for this situation of rural youth can be called the material and property situation, the low level of development of the socio-cultural infrastructure. In addition, rural youth associate difficulties in the implementation of life plans with a weak or complete insecurity of their rights, which predetermines a low assessment of the possibilities for realizing their needs and aspirations to improve their living standards. Weak security affects not only the deterioration of social well-being, but can lead to a decrease in the level of needs and aspirations among rural youth.

The acquisition of "independence" by young residents of the Russian countryside is due to both the disproportionate localization of their starting positions and the widespread spread of market relations and priorities. Rural youth motivate their professional status preferences by achieving material well-being and social comfort. Meanwhile, on the way of her personal activity there are multiple obstacles, the overcoming of which depends on the availability of different types of resources. Sociological studies allow us to conclude that rural youth in modern Russia belongs to low-resource groups of the population. They do not have power, economic, legal means of life support, her labor and cultural resources (education, profession, leisure) are mostly in short supply. The increasingly individualized nature of resource provision for Russian youth as a whole contrasts with their way of life, with the sphere of their preferences and opportunities.

If we take it as an axiom that people themselves determine their way of life in conditions independent of their choice, then it will be necessary to understand the extent to which these conditions influence the choice by people of their preferences and actions. This is where the polarization of living spaces in modern Russia, established in Russian sociological studies, comes to the rescue. Large cities with a developed industrial, financial, 
trade and socio-cultural infrastructure, a wide range of professional and household choices, corresponding to the standards of goods and conveniences, are at one extreme. At the other extreme, there are small urban and rural settlements that do not stand comparison for any of the listed indicators. These polar conditions predetermine, on the one hand, the leading position of young people in the capital and large cities in the accumulation of social advantages and resource potential, as well as in the most favorable development of new social practices, on the other hand, the position of outsiders for young people from small urban and rural settlements. However, in shaping their way of life, the Russian youth of the polar types of settlement is guided mainly by specifically "their" values: success, professionalism, property, and private life. In the content of her lifestyle, an increasing place is given to achievement-oriented attitudes, consumerism, addiction to "other things," an orientation toward the strategy of "life for good" with the construction of short life plans based on the principle of "living on credit".

The lifestyle of rural youth in Russia at the beginning of the 21 st century is formed under the influence of social exclusion and contains features of "rejection", which is justified by both foreign and domestic theoretical experiences. It should be noted that the growth of national prosperity and the policy of state social security do not eliminate inequality of opportunities among individuals and social groups; on the contrary, it multiplies in the course of globalization and consumerization of public life. Many people accumulate unfavorable living conditions that lead them to the position of socially ineffective groups of the population.

The general property of "rejection" of any individual or social group - the cumulation of unfavorable life circumstances - was especially clearly manifested in Russia of post-Soviet period. This fact made Russian sociologists to concretize and clarify it by analysing the real living conditions of various social groups first of all, young people. The issue of social exclusion is studied in Russian juvenology from the adaptive and riskological approaches' point of. Scholars, independently, determine the "deprivation effects" of Russian social stratification. It includes the transformation of youth from a definite social-demographic group into an ordinary demographic one. It can be subjected to multiple socio-economic, socio-legal, socio-political risks like many other groups. Thus, there is a danger of losing that significant social function that is entrusted to young people - the accumulation, enrichment and transmission of the experience of generations.

\section{Conclusion}

At present, an unfavorable demographic situation continues to develop in the Russian countryside and is caused by a number of factors:

- high unemployment rate

- insufficiently developed social infrastructure (medicine, education, cultural and leisure sphere, transport links with the district / regional / regional center)

- poor motivation for self-development due to low-status position

Forced labor migrations are associated, as a rule, with seasonal work (crop production, construction).

The rural population in Russia is steadily falling in all Federal Districts, with the exception of the Far East (in November 2018, the Republic of Buryatia and the TransBaikal Territory became part of the Far Eastern Federal District) Table 1 [43].

The current ethno-demographic and migration situation in the Rostov region represents the following picture:

- Since 2006 the whole population number has been decreasing, according to the Rosstat data. The estimated region population will be less than 4 million people by 2031 . The region rural population share is decreasing. In rural areas of the region, the number of 
the employable population has decreased to $26.7 \%$. The rate of birth in the region is lower and the mortality rate and the rate of natural population decline are higher than the Russian indicators. [45]. The dynamics of the population of the Rostov region also raises concerns [44]. Table 2.

Table 1. Rural population change by federal districts of the Russian Federation in 2018 (thousands of people)

\begin{tabular}{|c|c|c|c|c|}
\hline & \multicolumn{2}{|c|}{ Population at the beginning } & \multirow{2}{*}{$\begin{array}{l}\text { Rural } \\
\text { population } \\
\text { growth in } \\
2018\end{array}$} & \multirow{2}{*}{$\begin{array}{l}\text { In relation to the } \\
\text { number at the } \\
\text { beginning of the } \\
\text { period,\% }\end{array}$} \\
\hline & $8^{201}$ & 9201 & & \\
\hline $\begin{array}{l}\text { Russian Federation- } \\
\text { total } \\
\text { Including federal } \\
\text { district: }\end{array}$ & 37553.5 & 37327.2 & -226.3 & -0.6 \\
\hline Central & 6998.0 & 6982.2 & -15.8 & -0.2 \\
\hline North-Western & 2180.6 & 2162.3 & -18.3 & -0.8 \\
\hline Southern & 6157.4 & 6137.8 & -19.6 & -0.3 \\
\hline North-Caucasian & 4930.4 & 4919.6 & -10.8 & -0.2 \\
\hline Privolzhsky & 8302.5 & 8213.7 & -88.8 & -1.1 \\
\hline Ural & 2299.7 & 2280.0 & -19.7 & -0.9 \\
\hline Siberian & 5191.9 & 4412.9 & -779 & -15 \\
\hline Far East & 1493.2 & 2218.7 & 725.5 & 48.6 \\
\hline
\end{tabular}

Table 2. Population dynamics in the Rostov region (thousands of people)

\begin{tabular}{|c|c|c|c|}
\hline \multirow{2}{*}{ Years } & \multirow{2}{*}{ Total } & \multicolumn{2}{|c|}{ Including } \\
\cline { 3 - 4 } & & city & rural \\
\hline 1998 & 4387.6 & 2969.3 & 1418.3 \\
\hline 1999 & 4367.9 & 2953.1 & 1414.8 \\
\hline 2000 & 4340.8 & 2930.5 & 1410.3 \\
\hline 2002 & 4286.2 & 2892.0 & 1394.2 \\
\hline 2003 & 4396.7 & 2973.4 & 1423.3 \\
\hline 2004 & 4365.6 & 2952.4 & 1413.2 \\
\hline 2005 & 4334.4 & 2892.7 & 1441.7 \\
\hline 2010 & 4283.9 & 2879.1 & 1404.8 \\
\hline 2012 & 4260.6 & 2876.3 & 1381.3 \\
\hline 2013 & 4254.6 & 2878.3 & 1376.3 \\
\hline 2014 & 4243.8 & 2878.7 & 1365.1 \\
\hline 2015 & 4239.0 & 2875.5 & 1360.6 \\
\hline 2016 & 4233.7 & 2873.1 & 1357.3 \\
\hline 2017 & 4231.3 & 2874.0 & 1349.0 \\
\hline 2018 & 4220.4 & 2871.4 & \\
\hline
\end{tabular}

Under these circumstances, the situation with the young people migration from rural areas to cities is potentially highly risky. The abandoning of cultural customs and values of rural culture can explain it. It can be a real threat of the risk of outsiders increase, provided that they are unfavorably adapted to the urban lifestyle.

Circumstances develop in such a way that the sequence of tasks / problems does not dry out as they are solved, and each subsequent task / problem each time acquires the status of topical - it is in this sequence that the short-sighted pragmatism of youth groups "shortens" the life plans of ordinary members of the youth community. In essence, the given example 
of involvement on the basis of subordination is a variant of drawing new members of the community into the cycle of risky social practices, while the status of the performer does not cancel the status of an outsider.

Compensatory practices of overcoming socio-economic outsiders prevail among rural youth. This trend, as it is supported by unfavorable socio-economic conditions, does not allow young rural residents to feel confident in the prospects for future life. This fact of awareness of the personal prospects limitedness negatively affects the ambitions of young people self-realization.

Thus, migrating to the city, young villagers are subject to incorporation into the urban social environment. Despite the fact that the "semi-urban" culture carries the features of both rural and urban lifestyles, and for the same reason is less acceptable to newly-made urban residents. However, integrating into the youth community, at the same time, means full acceptance of the values and way of life of this youth group. As a result, young villagers who migrated to the city are forced to experience downward mobility when adapting to urban life and in the case of becoming familiar with the "semi-urban" culture, and in the case of integration into the urban youth subculture. And even if the process of lowering the intragroup status is viewed as a temporary phenomenon, the risk of being rejected or drawn into by the youth community does not decrease, since the state of uncertainty of status, neither "our own", but also not "alien" remains.

The disparities in education and employment lead to a situation of different life chances among young people in the city and village. Young people from villages have to combine work and study, which negatively affects the quality of education. At the same time, the overwhelming majority of young villagers are afraid to be left without means of subsistence, to lose or not be able to find work. This uncertainty in life prospects gives rise to a feeling of insecurity among the youth of the village.

In essence, adaptation to an urban lifestyle can transform the lifestyle of a rural young people arriving in a city, not by means of inclusion and integration, but through the threat of being excluded. The paradox is that the optimistic hopes of young villagers of improving their living standards by acquiring education and becoming involved in the urban lifestyle in reality turn into an incline in the risk of downward social mobility. However, negative perspectives are not taken into account by rural youth.

Making conclusions, we can highlight that the chance of being successful in intergenerational competition, modern Russian young people are fragmented into groups, communities and sometimes sects. Thus, it has certain risks and thereby reduces its potential. It is not easy for rural youth to establish themselves in urban life. However, the research clearly shows that notwithstanding the influence of negative socio-cultural factors, young people from villages are still full of optimism and self-assurance. This optimism is the most valuable resource and social capital. Let us hope that this margin of safety will be sufficient to overcome hardships and obstacles in achieving life goals.

\section{References}

1. S. Friedman, M.Billig, Children and Youth Services Review, 84, 103-109 (2018), https://doi.org/10.1016/j.childyouth.2017.10.026

2. N. Black, K. Scott, M. Shucksmith, The Journal of Rural Studies, 84, 264-275, (2019), https://doi.org/10.1016/j.jrurstud.2018.09.008

3. S. Daenekindt, Poetics, 84, (2019), https://doi.org/10.1016/j.poetic.2018.12.002

4. L. Nielson, J. Wiles, A. Anderson, Journal of Aging Studies, 49, 25-30, (2019), https://doi.org/10.1016/j.jaging.2019.03.003 
5. J. Stanley, J. Stanley, C. Balbontin, D. Hensher, Transportation Research: Part A, 125, 223-233, (2019), https://doi.org/10.1016/j.tra.2018.05.015

6. S. Jiang, S. Sek-yumNgai, Children and Youth Services Review, 116, (2020), https://doi.org/10.1016/j.childyouth.2020.105182

7. G. Crous, J. Bradshaw, Children and Youth Services Review, 80, 129-139, (2017), https://doi.org/10.1016/j.childyouth.2017.06.062

8. Y.Xia, Z.Ma, Public Health, 186, 129-136, (2020), https://doi.org/10.1016/j.puhe.2020.05.038

9. M. Gummerum, B.López-Pérez, Cognitive Development, 54, (2020), https://doi.org/10.1016/j.cogdev.2020.100874

10. T.I. Barsukova, L.A. Shvachkina, V.I. Rodionova, L.A. Saenko, S.T. Baranov, Modern Journal of Language Teaching Methods, 8, 210-217, (2018)

11. N.Y. Belikova, A.V. Dyatlov, M.A. Shostak, V.V. Kovalev, I.M. Vakula, T.V. Koshel, Humanidades \& INOVACO, 8, 94-103, (2021)

12. M.V. Beshtokov, V.I. Odintsova, O.Y. Uzunova, G.V. Dashkevich, A.S. Demidenko, D.N. Mishchenko, Turismo-Estudos E Praticas, (2019)

13. N.Y. Belikova, E.U. Ponomareva, V.V. Kotlyarova, S.V. Yushina, L.I. Abbasova, A.T. Latysheva, Revista Genero \& Direito, 9, 846-859, (2020)

14. B.Meskhi, S.Ponomareva, E.Ugnich, M. Drozd, Trends in the development of psychopedagogical education in the conditions of transitional society (ICTDPP-2019), 70, (2019), DOI: $10.1051 /$ shsconf $/ 20197003005$

15. L.I. Belyaeva. World of Russia, 2, (2006)

16. L.T. Volchkova, V.N. Minina, Sociological Studies, 1, (1999)

17. M. Rutter, N. Madge, Cycles of Disadvantage: A Review of Research (L.: Heinemann, 1976)

18. S. Paugam, Journal of European Social Policy, 6, 4, (1996)

19. P. Abrahamson, Social sciences and modernity, 2, (2001)

20. S.A. Nikolsky, Agrarian course of Russia (M., 2003)

21. V. V. Patsiorkovsky, Rural Russia: 1991-2001, (Moscow: Finance and Statistics, 2003)

22. P.P.Belikiy, M.Yu. Morekhina, Sociological Studies, 12, (2004)

23. V.I. Staroverov, Sociological Studies, 12, (2004)

24. O.I. Karpukhin, Sociological Studies, 3, (2003)

25. K.V. Rubchevsky, Social sciences and modernity, 3, (2003)

26. G.A. Cherednichenko, Youth of Russia: Social orientations and life paths ( $\mathrm{SPb}$.: Publishing house of Russian Christian Academy for the Humanities, 2004)

27. V. V. Morozov, A. P. Skrobov, Socio-political journal, 1, (1998)

28. V.I. Chuprov, Yu.A. Zubok, Socio-political journal, 6, (1996)

29. V.I. Chuprov, Yu.A. Zubok, K. Williams, Youth in a risk society (Moscow: Nauka, 2001)

30. O. N. Yanitskiy, Sociology of risk. (M .: Publishing house LVS, 2003)

31. P. Abrahamson, Social sciences and modernity, 2, (2001)

32. J. Welshman, Underclass: A History of the Excluded, 1880-2000, (London, GBR, 2007) 
33. D.L. Konstantinovsky, Dynamics of inequality. Russian youth in a changing society: orientations and paths in the field of education (from the 1960s to the 2000s), (M .: Editorial URSS, 1999)

34. P. Littlewood, Social exclusion in Europe: problems and paradigms, (Routledge, 2017)

35. B. Jordan, A Theory of Poverty and Social Exclusion, (Polity Press, Cambridge, UK, 1996)

36. M. Roche, R. Van Berkel, European Citizenship and Social Exclusion, (Ashgate, 1997)

37. H. Silver, Social exclusion and social solidarity: Three paradigms, (1994)

38. M. A. Kuzhelev, State and municipal administration. Scientific notes, 3 (2019)

39. M. Yudkevich, https://ioe.hse.ru/news/205794564.html

40. E. I. Zasedateleva, Humanitarian research, 3 (20), 27 (2018)

41. I. A. Ilyin, Our tasks. Historical tasks and the future of Russia, (M. 1992)

42. G.P. Fedotov, The fate and sins of Russia, (SPb .: Sofia, 1992)

43. On the state of rural areas in the Russian Federation in 2018: an annual report on the results of monitoring (sixth edition), M. FGBNU "Rosinformagrotech" (2020)

44. I. V. Bessmertny, V. V. Latun, Yu. Yu. Merinova, A. D. Khovanskiy, Earth Science, 3, $28(2021)$

45. V.A. Tishkov, Interethnic and confessional relations in the Southern Federal District. Expert Report (M. Rostov-on-Don, 2013) 